\title{
MOLECULAR CLONING AND EXPRESSION OF YELLOWFIN PORGY (ACANTHOPAGRUS LATUS HOUTTUYN) GROWTH HORMONE cDNA
}

\author{
Hual-Jen Tsai, ${ }^{*}$ Ku-Lin Lin and Thomas T. Chen $\dagger$ \\ Institute of Fisheries Science, National Taiwan University, Taipei, Taiwan 10764, Republic of China \\ (Fax: 886-2-363-8483); and †Center of Marine Biotechnology, University of Maryland, Baltimore, \\ MD 21202, U.S.A.
}

(Received 14 August 1992; accepted 25 September 1992)

\begin{abstract}
The growth hormone cDNA of yellowfin porgy (ypGH cDNA) consisted of 915 base pairs. 2. The deduced amino acid (aa) sequence showed that the pre-GH comprised 204 residues, of which the first 17 residues formed a signal peptide.

3. Comparison of aa sequence of ypGH to seabream, tuna, rainbow trout and chum salmon showed that ypGH shared 95.1, 94.1, 65.3 and $62.4 \%$ homology with these species, respectively.

4. By expressing the ypGH cDNA in E. coli, a polypeptide around 23 kilodaltons (kDa) was found which was immunoreactive to $\mathrm{GH}$ antibody.
\end{abstract}

\section{INTRODUCTION}

Growth hormone (GH) is one of the major important polypeptide hormones produced in the anterior pituitary cells to regulate growth and metabolism in vertebrates. Since fish constitute an enormous variety of vertebrate species, comparative studies on the primary structures of teleostean $\mathrm{GHs}$, the predicted secondary structures and the regulation of their expression will provide a significant insight to the understanding of the structure-function relationships, evolutionary implications and biological actions of GH.

Yellowfin porgy is a major marine aquaculture fish, especially in Asia. Taxonomically, it is classified as order Perciformes, suborder Percoidei and family Sparidae. Physiologically, it is a protandrous hermaphroditic fish (Chang and Yueh, 1990). However, the molecular biological studies of genes involved in its growth have been limited, although various fish $\mathrm{GH}$ genes have been studied: those of carp (Chiou et al., 1990), eel (Saito et al., 1988), rainbow trout (Agellon and Chen, 1986; Agellon et al., 1988), salmon (Johansen et al., 1989; Hew et al., 1989; Sekine et al., 1985, 1989; Gonzalez-Villasenor et al., 1988), seabream (Momota et al., 1988; Funkenstein et al., 1991), tilapia (Rentier-Delrue et al., 1989) and tuna (Sato et al., 1988).

We here describe the molecular structure of yellowfin porgy growth hormone (ypGH) cDNA. In addition to providing the needed information on the primary structure of the ypGH cDNA, this cDNA was genetically engineered into an expression vector to confirm that ypGH cDNA encoded GH. The latter may be used for producing recombinant GH (rGH)

*To whom correspondence should be addressed. in micro-organisms for research and other applications.

\section{MATERIALS AND METHODS}

\section{cDNA library construction}

Total RNA was extracted from pituitary glands by following the modified phenol-chloroform-SDS method (Chen, 1980). Poly (A) ${ }^{+}$-RNA was prepared on an oligo (dT)-cellulose column (Aviv and Leder, 1972) and used as a template for the synthesis of cDNA (Agellon and Chen, 1986). The cDNAs were inserted at the Eco Rl site of lambda gt 10 (Strategene, CA) and the resulting chimeric phages were amplified in $E$. coli $\mathrm{C} 600 \mathrm{hfl}^{-}$.

\section{Screening}

The rainbow trout GH cDNA (rtGH cDNA) (Agellon and Chen, 1986) was used as a probe for isolating clones containing ypGH cDNA from the cDNA library by the plaque hybridization method (Maniatis et al., 1982). Approximately $1 \times 10^{6}$ recombinant bacteriophage were plated on LB plates $\left(3 \times 10^{4} \mathrm{pfu} / \mathrm{plate}\right)$ and then transferred to the membranes. After blotting, the membranes were hybridized to the $\left.{ }^{32} \mathrm{P}\right]$-labeled rtGH cDNA. Hybridization was carried out in a buffer containing $5 \times$ Denhardt's solution $(1 \times$ Denhardt's: $0.02 \%$ Ficoll, $0.02 \%$ polyvinylpyrolidone and $0.02 \%$ bovine serum albumin), $5 \times$ SSPE $(1 \times$ SSPE: $0.15 \mathrm{M} \mathrm{NaCl}$, $11 \mathrm{mM} \mathrm{NaH}{ }_{2} \mathrm{PO}_{4}, 1 \mathrm{mM}$ EDTA), $0.1 \%$ SDS and $100 \mu \mathrm{g} / \mathrm{ml}$ denatured salmon sperm DNA at $42^{\circ} \mathrm{C}$ for $16 \mathrm{hr}$. The membranes were washed three times $(10 \mathrm{~min}$ each) at room temperature in a solution containing $0.1 \%$ SDS and $1 \times$ SSPE, followed by another three washes in a solution of $0.1 \%$ SDS and 
$0.2 \times \mathrm{SSPE}$ at $60^{\circ} \mathrm{C}$. Positive clones were purified for further analysis.

Nucleotide sequence determination and amino acid deduction

The GH cDNA inserts were subcloned into the EcoRI site of pUC18 for further restriction map analysis. Two DNA fragments generated by digesting the entire cDNA with ClaI were further subcloned into the phagemid, pGEM-7Zf $(+)$, for nucleotide sequence determination (Sanger et al., 1977), using synthetic oligomers 5'-GATTTAGGTGACACTATAG-3' and 5'-TAATACGACTCACTATAGGG-3' as sequencing primers.

The amino acid (aa) sequences of $\mathrm{GH}$ from other fish species were retrieved from the GeneBank and National Biomedical Research Foundation data bases for comparison. Alignment of aa sequences was carried out by introducing gaps to maximize the identity and similarity, using the Wisconsin Package.

\section{Expression of ypGH cDNA in E. coli}

The cDNA fragment encoding the mature ypGH was amplified by the polymerase chain reaction (PCR) following the standard conditions (Innis and Gelfand, 1990). PCR primers, 5'-ATATCATATGCAGCCGATCACAGACGGCCAGCG-3' (ATAT, $N d e$ I site and ATG preceded the sense strand of +104 to +126$)$ and 5 -ATATAAGCTTTTACTACAGGGTGCAGTTGGC-3' (ATAT and HindIII site preceded the antisense strand of +667 to +650 and one more stop codon, TAA) were used for synthesizing the mature region of ypGH cDNA. The PCR product was ligated into the SmaI site of pUC19. The resulting cDNA fragment released from the vector by cutting with $N d e I$ and $S a l$ I was ligated into the expression vector, pRE (Reddy et al., 1989), which was digested with $N d e I$ and $S a l I$. This construct was then introduced into $E$. coli $\mathrm{MZ1}$. The transformants were grown in LB media under the permissive temperature $\left(30^{\circ} \mathrm{C}\right)$ to an $\mathrm{OD}_{650}$ of 0.5 and then shifted to $41^{\circ} \mathrm{C}$ for approximately $2 \mathrm{hr}$ for the induction of ypGH synthesis. Harvested cells were lysed and dissolved in a sample buffer (Laemmli, 1970) and analyzed by SDS-PAGE on a $20 \%$ polyacrylamide gel (Hames, 1990).

\section{Western blot analysis}

The protein bands on the gel were transferred to a polyvinylidene difluoride membrane (Towbin et al., 1979). The resulting membrane was incubated in a blocking solution $[0.5 \%$ skim milk in $50 \mathrm{mM}$ Tris- $\mathrm{HCl}, 0.5 \mathrm{M} \mathrm{NaCl}, \mathrm{pH} 7.5$ (TBS)] at $4 \mathrm{C}$ overnight, and then in a fresh blocking solution containing a rabbit antiserum raised against the natural chum salmon $\mathrm{GH}(\mathrm{csGH})$ for $1 \mathrm{hr}$ at $37^{\circ} \mathrm{C}$. The membrane was washed three times in a TBST solution (TBS containing $0.05 \%$ Tween 20 ), then incubated in the blocking solution containing goat anti-rabbit IgG conjugated with alkaline phosphatase for $1 \mathrm{hr}$ at $37^{\circ} \mathrm{C}$. The immunoreactive band was visualized by reacting the blot in a solution containing color-developing reagents (5-bromo-4-chloro-3indolylphosphate and nitroblue tetrazolium) for 5-30 min at room temperature.

\section{RESULTS AND DISCUSSION}

Isolation and nucleotide sequence of ypGH $c D N A$

A cDNA library containing $1 \times 10^{6}$ recombinant phage clones was constructed. About 40 putative
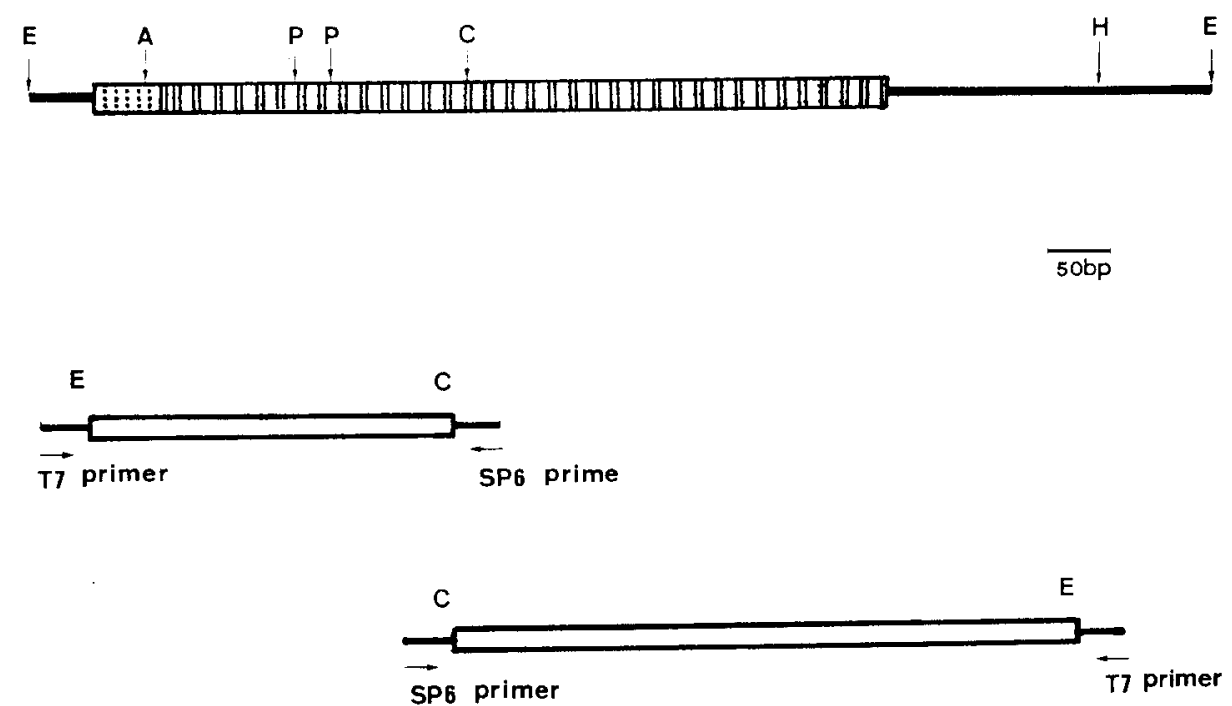

Fig. 1. A partial restriction map and sequence strategy. (A) Restriction and map of yellowfin porgy GH cDNA. The $5^{\prime}$-untranslated region (left thick line), the signal peptide coding region (dot box), the mature GH coding region (hatch box) and the $3^{\prime}$-untranslated region (right thick line) are shown. A, AhaII; C, ClaI; E, Eco RI; H, HindIII; P, Pst I sites. (B) Two subclones derived from ypGH cDNA clone used in nucleotide sequence determination using T7 or SP6 primers. 
positive clones were obtained after screening over $2 \times 10^{6}$ phages. Southern blot analysis showed that one of the longest positive clones contained an insert of $915 \mathrm{bp}$. A partial restriction map is presented in Fig. 1(A).

Since there was a unique internal Cla I site, giving two fragments of $575 \mathrm{bp}$ and $340 \mathrm{bp}$, respectively, these two DNA fragments were separately subcloned into pGEM-7Zf $(+)$ for sequencing. The strategy of nucleotide (nt) sequence determination is shown in Fig. 1(B). As summarized in Fig. 2, the cDNA insert contained a single open reading frame of $612 \mathrm{nt}$ located at nt positions 53-664, which encoded 204 aa residues. The translation initiation codon (ATG) was located at nt positions 53-55, and was preceded with $52 \mathrm{nt}$ of the untranslated leader sequence. The translation termination codon TAG (nt positions 665-667) was followed by a 3'end untranslated region of $231 \mathrm{nt}$ including the polyadenylation signal (AATAAA) at nt $874-879,19$ bases upstream from the beginning of the $\operatorname{poly}(\mathrm{A})$ tail.

Four tandem direct repeat sequences, $5^{\prime}$ GAACC $(\mathrm{A} / \mathrm{T})-3^{\prime}$, were observed in the $5^{\prime}$ untranslated region (nt 26-49). Although the biological significance of these direct repeat sequences is not understood, different numbers of these sequences

\begin{tabular}{|c|c|c|c|c|c|c|c|c|c|c|c|c|c|c|c|}
\hline $\begin{array}{r}53 \\
-17\end{array}$ & $\begin{array}{l}\text { AMG } \\
\text { Met }\end{array}$ & $\begin{array}{l}\text { GAC } \\
\text { AsP }\end{array}$ & $\begin{array}{l}\text { AGA } \\
\text { Arg }\end{array}$ & $\begin{array}{l}\text { GIG } \\
\text { Val }\end{array}$ & $\begin{array}{l}\text { GHe } \\
\text { Val }\end{array}$ & $\begin{array}{l}\text { Cre } \\
\text { Leu }\end{array}$ & $\begin{array}{l}\text { ATG } \\
\text { Met }\end{array}$ & $\begin{array}{l}\text { CrG } \\
\text { Leu }\end{array}$ & $\begin{array}{l}\text { TCG } \\
\text { Ber }\end{array}$ & $\begin{array}{l}\text { GIG } \\
\text { Vel }\end{array}$ & $\begin{array}{l}\text { CIG } \\
\text { Leu }\end{array}$ & $\begin{array}{l}\text { TCT } \\
\text { ser }\end{array}$ & $\begin{array}{l}\text { CHG } \\
\text { Leu }\end{array}$ & $\begin{array}{l}\text { Gec } \\
\text { Gly }\end{array}$ & \\
\hline $\begin{array}{l}95 \\
-3\end{array}$ & $\begin{array}{l}\text { GTC } \\
\text { Val }\end{array}$ & $\begin{array}{l}\text { TCC } \\
\text { ger }\end{array}$ & $\begin{array}{l}\text { TCT } \\
\text { Ber }\end{array}$ & CAO & $\begin{array}{l}\text { CCG } \\
\text { Pro }\end{array}$ & $\begin{array}{l}\text { AlC } \\
\text { Ile }\end{array}$ & $\begin{array}{l}\text { ACA } \\
\text { Thr }\end{array}$ & $\begin{array}{l}\text { GAC } \\
\mathbf{A s p}\end{array}$ & $\begin{array}{l}\text { GeC } \\
\text { GIY }\end{array}$ & $\begin{array}{l}\text { CAG } \\
\text { G1n }\end{array}$ & $\begin{array}{l}\text { CET } \\
\text { Arg }\end{array}$ & $\begin{array}{l}\text { CHG } \\
\text { Leu }\end{array}$ & $\begin{array}{l}\text { ITC } \\
\text { Phe }\end{array}$ & $\begin{array}{l}\text { TCC } \\
\text { ser }\end{array}$ & \\
\hline $\begin{array}{r}137 \\
12\end{array}$ & $\begin{array}{l}\text { ATC } \\
\text { Ile }\end{array}$ & $\begin{array}{l}\text { GCT } \\
\text { Ala }\end{array}$ & $\begin{array}{l}\text { GrC } \\
\text { val }\end{array}$ & $\begin{array}{l}\text { Aec } \\
\text { ser }\end{array}$ & $\begin{array}{l}\text { AGA } \\
\text { Arg }\end{array}$ & $\begin{array}{l}\text { GTI } \\
\text { Val }\end{array}$ & $\begin{array}{l}\text { CAA } \\
\text { GIn }\end{array}$ & $\begin{array}{l}\text { CAC } \\
\text { His }\end{array}$ & $\begin{array}{l}\text { CTC } \\
\text { Leu }\end{array}$ & $\begin{array}{l}\text { CAC } \\
\text { His }\end{array}$ & $\begin{array}{l}\text { CTG } \\
\text { Leu }\end{array}$ & $\begin{array}{l}\text { CTC } \\
\text { Leu }\end{array}$ & $\begin{array}{l}\text { GCT } \\
\text { Ala }\end{array}$ & $\begin{array}{l}\text { Care } \\
\text { Gln }\end{array}$ & 7 \\
\hline $\begin{array}{r}179 \\
26\end{array}$ & $\begin{array}{l}\text { AGA } \\
\text { Arg }\end{array}$ & $\begin{array}{l}\text { CrC } \\
\text { Leu }\end{array}$ & $\begin{array}{l}\text { TTC } \\
\text { Phe }\end{array}$ & ler & Asp & he & $\begin{array}{l}\text { GAG } \\
\text { Glu }\end{array}$ & $\begin{array}{l}\text { AGC } \\
\text { Ber }\end{array}$ & $\begin{array}{l}\text { TCT } \\
\text { Bar }\end{array}$ & $\begin{array}{l}\text { Crg } \\
\text { Leu }\end{array}$ & $\begin{array}{l}\text { CAG } \\
\text { GIn }\end{array}$ & $\begin{array}{l}\text { ACT } \\
\text { Thr }\end{array}$ & $\begin{array}{l}\text { GAG } \\
\text { GIu }\end{array}$ & $\begin{array}{l}\text { GAG } \\
\text { Glu }\end{array}$ & \\
\hline $\begin{array}{l}21 \\
40\end{array}$ & $\begin{array}{l}\text { CAA } \\
\text { GIn }\end{array}$ & $\begin{array}{l}\text { CGA } \\
\text { Arg }\end{array}$ & $\begin{array}{l}\text { CAG } \\
\text { GIn }\end{array}$ & eu & $\begin{array}{l}\mathrm{AC} \\
\mathrm{sn}\end{array}$ & $\begin{array}{l}\text { An } \\
y^{8}\end{array}$ & $\begin{array}{l}\text { ATC } \\
\text { Ile }\end{array}$ & $\begin{array}{l}\text { The } \\
\text { Phe }\end{array}$ & $\begin{array}{l}\text { CTG } \\
\text { Leu }\end{array}$ & $\begin{array}{l}\text { CAG } \\
\text { GIn }\end{array}$ & $\begin{array}{l}\text { GAT } \\
\text { Asp }\end{array}$ & $\begin{array}{l}\text { TrC } \\
\text { Phe }\end{array}$ & $\begin{array}{l}\text { TGT } \\
\text { CYs }\end{array}$ & $\begin{array}{l}\text { AaC } \\
\text { Asn }\end{array}$ & \\
\hline $\begin{array}{r}263 \\
54\end{array}$ & $\begin{array}{l}\text { TCT } \\
\text { Ber }\end{array}$ & $\begin{array}{l}\text { GAT } \\
\text { Asp }\end{array}$ & $\begin{array}{l}\text { TAC } \\
\text { TYI }\end{array}$ & Ile & Ie & ec & $\begin{array}{l}\text { Cce } \\
\text { Pro }\end{array}$ & $\begin{array}{l}\text { ATC } \\
\text { Ile }\end{array}$ & $\begin{array}{l}\text { GAC } \\
\text { Asp }\end{array}$ & $\begin{array}{l}\text { AAG } \\
\text { Lys }\end{array}$ & $\begin{array}{l}\text { CAC } \\
\text { His }\end{array}$ & $\begin{array}{l}\text { GAG } \\
\text { Glu }\end{array}$ & $\begin{array}{l}\text { ACA } \\
\text { Thr }\end{array}$ & $\begin{array}{l}\text { CAG } \\
\text { GIn }\end{array}$ & \\
\hline $\begin{array}{l}05 \\
68\end{array}$ & $\begin{array}{l}\text { Coc } \\
\text { Arg }\end{array}$ & $\begin{array}{l}\text { AGC } \\
\text { Ber }\end{array}$ & $\begin{array}{l}\text { TCA } \\
\text { Ber }\end{array}$ & $\begin{array}{l}\text { GIG } \\
\text { Val }\end{array}$ & $\begin{array}{l}\text { TG } \\
\text { eu }\end{array}$ & $\begin{array}{l}\mathrm{AO} \\
\mathrm{y}^{\circ}\end{array}$ & $\begin{array}{l}\text { CTG } \\
\text { Leu }\end{array}$ & $\begin{array}{l}\text { CTG } \\
\text { Leu }\end{array}$ & $\begin{array}{l}\text { TCT } \\
\text { ser }\end{array}$ & $\begin{array}{l}\text { ATC } \\
\text { Ile }\end{array}$ & $\begin{array}{l}\text { TCC } \\
\text { Ber }\end{array}$ & $\begin{array}{l}\text { TAT } \\
\text { TYY }\end{array}$ & $\begin{array}{l}\text { CGA } \\
\text { Arg }\end{array}$ & $\begin{array}{l}\text { TrG } \\
\text { Leu }\end{array}$ & $\mathbf{8}$ \\
\hline $\begin{array}{r}347 \\
82\end{array}$ & $\begin{array}{l}\text { CTC } \\
\text { Val }\end{array}$ & $\begin{array}{l}\text { GAC } \\
\text { GIu }\end{array}$ & er & $\begin{array}{l}\text { TEC } \\
\text { Trp }\end{array}$ & $\begin{array}{l}\text { AG } \\
11 u\end{array}$ & The & $\begin{array}{l}\text { Ccc } \\
\text { Pro }\end{array}$ & $\begin{array}{l}\text { AGT } \\
\text { ser }\end{array}$ & $\begin{array}{l}\text { CGT } \\
\text { Arg }\end{array}$ & $\begin{array}{l}\text { TCT } \\
\text { Ber }\end{array}$ & $\begin{array}{l}\text { CTG } \\
\text { Leu }\end{array}$ & $\begin{array}{l}\text { GCT } \\
\text { Ala }\end{array}$ & $\begin{array}{l}\text { GGC } \\
\text { GIY }\end{array}$ & $\begin{array}{l}\text { GGT } \\
\text { GlY }\end{array}$ & \\
\hline $\begin{array}{r}389 \\
96\end{array}$ & $\begin{array}{l}T C H \\
B \in I\end{array}$ & $\begin{array}{l}\text { CCH } \\
\text { Ala }\end{array}$ & ra & $\begin{array}{l}\text { GG } \\
\text { irg }\end{array}$ & $\mathrm{BC}$ & 110 & $\begin{array}{l}\text { AT'T } \\
\text { Ile }\end{array}$ & $\begin{array}{l}\text { TCA } \\
\text { Ber }\end{array}$ & $\begin{array}{l}\text { ccc } \\
\text { Pro }\end{array}$ & $\begin{array}{l}\text { MAA } \\
\text { LYB }\end{array}$ & $\begin{array}{l}\text { CrG } \\
\text { Leu }\end{array}$ & $\begin{array}{l}\text { TCI } \\
\text { Ber }\end{array}$ & $\begin{array}{l}\text { GAG } \\
\text { GIu }\end{array}$ & $\begin{array}{l}\text { Cre } \\
\text { Leu }\end{array}$ & \\
\hline $\begin{array}{r}31 \\
110\end{array}$ & $\begin{array}{l}\text { AAG } \\
\text { LyB }\end{array}$ & $\begin{array}{l}\text { MCA } \\
\text { Thr }\end{array}$ & $\begin{array}{l}\text { Goc } \\
\text { G1Y }\end{array}$ & $\begin{array}{l}\text { AlC } \\
\text { Ile }\end{array}$ & $\begin{array}{l}\text { AT } \\
\text { is }\end{array}$ & Ieu & $\begin{array}{l}\text { CHG } \\
\text { Leu }\end{array}$ & $\begin{array}{l}\text { AlC } \\
\text { Ile }\end{array}$ & $\begin{array}{l}\text { AGG } \\
\text { Arg }\end{array}$ & $\begin{array}{l}\text { GCC } \\
\text { Ala }\end{array}$ & $\begin{array}{l}\mathbf{A A T} \\
\mathbf{A s n}\end{array}$ & $\begin{array}{l}\text { GAG } \\
\text { Glu }\end{array}$ & $\begin{array}{l}\text { GAT } \\
\text { ABP }\end{array}$ & $\begin{array}{c}\text { GGA } \\
\text { G1Y }\end{array}$ & \\
\hline $\begin{array}{l}73 \\
124\end{array}$ & $\begin{array}{l}\text { GCA } \\
\text { Ala }\end{array}$ & 114 & $\begin{array}{l}\text { TC } \\
\text { eu }\end{array}$ & $\begin{array}{l}\text { The } \\
\text { Phe }\end{array}$ & $\begin{array}{l}\text { Cl } \\
\text { ro }\end{array}$ & Ap & $\begin{array}{l}\text { AGC } \\
\text { Ber }\end{array}$ & $\begin{array}{l}\text { TCC } \\
\text { ser }\end{array}$ & $\begin{array}{l}\text { GCC } \\
\text { Ala }\end{array}$ & $\begin{array}{l}\text { CTC } \\
\text { Leu }\end{array}$ & $\begin{array}{l}\text { CAG } \\
\text { GIn }\end{array}$ & $\begin{array}{l}\text { CTG } \\
\text { Leu }\end{array}$ & $\begin{array}{l}\text { GCT } \\
\text { Ala }\end{array}$ & $\begin{array}{l}\text { CCI } \\
\text { Pro }\end{array}$ & \\
\hline $\begin{array}{l}515 \\
138\end{array}$ & $\begin{array}{l}\text { TAY } \\
\text { TYY }\end{array}$ & $\begin{array}{l}\text { GGA } \\
\text { GIY }\end{array}$ & $\begin{array}{l}\text { GAC } \\
\text { Asp }\end{array}$ & $\begin{array}{l}\text { TAC } \\
\text { TYY }\end{array}$ & $\begin{array}{l}\text { MAC } \\
\text { Tyr }\end{array}$ & CAA & $\begin{array}{l}\text { AGT } \\
\text { Ber }\end{array}$ & $\begin{array}{l}\text { CCG } \\
\text { Pro }\end{array}$ & $\begin{array}{l}\text { GGC } \\
\text { GIY }\end{array}$ & $\begin{array}{l}\text { Acc } \\
\text { Thr }\end{array}$ & $\begin{array}{l}\text { GAC } \\
\text { Asp }\end{array}$ & $\begin{array}{l}\text { GAG } \\
\text { Glu }\end{array}$ & $\begin{array}{l}\text { TCG } \\
\text { Ber }\end{array}$ & $\begin{array}{l}\text { CTG } \\
\text { Ieu }\end{array}$ & \\
\hline $\begin{array}{l}57 \\
52\end{array}$ & $\begin{array}{l}\text { AGA } \\
\text { Arg }\end{array}$ & $\begin{array}{l}\text { CGA } \\
\text { Arg }\end{array}$ & $\begin{array}{l}\text { Acc } \\
\text { Thr }\end{array}$ & $\begin{array}{l}\text { THC } \\
\text { Tyr }\end{array}$ & $\begin{array}{l}\text { GAA } \\
\text { Glu }\end{array}$ & $\begin{array}{l}\text { ChA } \\
\text { Leu }\end{array}$ & $\begin{array}{l}\text { Let } \\
\text { Leu }\end{array}$ & $\begin{array}{l}\text { GCC } \\
\text { Ala }\end{array}$ & $\begin{array}{l}\text { TGT } \\
\text { CYs }\end{array}$ & $\begin{array}{l}\text { TTC } \\
\text { Phe }\end{array}$ & $\begin{array}{l}\text { AAA } \\
\mathbf{I Y s}\end{array}$ & $\begin{array}{l}\text { AAA } \\
\text { LY's }\end{array}$ & $\begin{array}{l}\text { GAC } \\
\text { Asp }\end{array}$ & $\begin{array}{l}\text { ATG } \\
\text { Met }\end{array}$ & \\
\hline $\begin{array}{l}599 \\
166\end{array}$ & $\begin{array}{l}\text { CAC } \\
\text { IIs }\end{array}$ & $\begin{array}{l}\text { AAG } \\
\text { Lys }\end{array}$ & $\begin{array}{l}\text { Gre } \\
\text { Val }\end{array}$ & $\begin{array}{l}\text { Gad } \\
\text { Glu }\end{array}$ & $\begin{array}{l}\text { ACC } \\
\text { Thr }\end{array}$ & TyC & $\begin{array}{l}\text { LHG } \\
\text { Leu }\end{array}$ & $\begin{array}{l}\mathrm{ACA} \\
\mathrm{Thr}\end{array}$ & $\begin{array}{l}\text { Gro } \\
\text { Val }\end{array}$ & $\begin{array}{l}\text { GCA } \\
\text { Ala }\end{array}$ & $\begin{array}{l}\text { AAA } \\
\text { Lys }\end{array}$ & $\begin{array}{l}\text { Tet } \\
\text { Cys }\end{array}$ & $\begin{array}{l}\text { AGA } \\
\text { Arg }\end{array}$ & $\begin{array}{l}\text { CTC } \\
\text { Leu }\end{array}$ & $\begin{array}{l}640 \\
179\end{array}$ \\
\hline $\begin{array}{l}541 \\
180\end{array}$ & $\begin{array}{l}\text { TCH } \\
\text { ger }\end{array}$ & $\begin{array}{l}\text { CCA } \\
\text { pro }\end{array}$ & $\begin{array}{l}\text { GAG } \\
\text { GIu }\end{array}$ & $\begin{array}{l}\text { GCC } \\
\text { Ala }\end{array}$ & $\begin{array}{c}\text { AaC } \\
\mathbf{A g n} \\
\quad\end{array}$ & Cys & $\begin{array}{c}\text { ACC } \\
\text { Thr } \\
\text { * }\end{array}$ & $\begin{array}{l}\text { Cro } \\
\text { Leu }\end{array}$ & MAG & \multicolumn{5}{|c|}{ 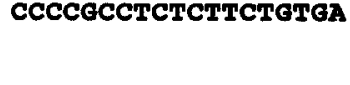 } & $\begin{array}{l}68 \\
18\end{array}$ \\
\hline 12 & AA & & . & & & & & & & & & & & & \\
\hline
\end{tabular}

Fig. 2. Nucleotide (nt) sequence of yellowfin porgy GH cDNA and the predicted aa sequence of the pre-hormone. The nt was numbered beginning with the first $n t$ at the $5^{\prime}$ end. The polyadenylation signal, AATAAA, is indicated by a box. The number on the second line of each row indicates the order of aa position. Pre-ypGH contains a signal peptide of 17 aa residues (aa -17 to -1 ) and a mature protein of 187 aa residues (aa 1 to 187 ). Potential $N$-glycosylation site is marked by an asterisk. 
have been observed in the $5^{\prime}$ untranslated region of almost all GH mRNA species studied to date (Sekine et al., 1985; Agellon and Chen 1986; GonzalezVillasenor et al., 1988; Momota et al., 1988; Sato et al., 1988; Saito et al., 1988; Funkenstein et al., 1991). Since the $3^{\prime}$ end of the eukaryotic 18S rDNA contained a sequence of $3^{\prime}$-UUUGGA-5' (Chan et al., 1984), it is conceivable that the observed direct repeat sequence of $5^{\prime}-\mathrm{GAACC}(\mathrm{A} / \mathrm{T})-3^{\prime}$ located at 5 -untranslated region of GH mRNA may be involved in the binding of the mRNA to the $40 \mathrm{~S}$ ribosomal subunit in the formation of the transiation initiation complex (Nakashima et al., 1980). Furthermore, it is of interest to note that, unlike the GH mRNA of bluefin tuna, the GH mRNA of yellowfin porgy, chum salmon, tuna or humans does not contain a direct repeat sequence of 5'-CTGTAGCCCCGCCTCTCTGATGACGT-3' at the $3^{\prime}$ untranslated region (Sato et al., 1988).

The nt sequence of the translated region of ypGH cDNA was compared to that of the other fish species. ypGH cDNA differed from that of the red seabream (Momota et al., 1988) and tuna (Sato et al., 1988) by 23 and $60 \mathrm{nt}$ out of a total $612 \mathrm{nt}$, respectively. Hence, the translated region of ypGH cDNA shared a 96.2 and $90 \%$ identity at the nt sequence level with those of red seabream and tuna.
Comparison of the deduced aa sequence of ypGH with those of other fish species

The predicted aa sequence of the yp-pre-GH polypeptide is summarized in Fig. 2. Since the authentic ypGH has not been isolated, the first aa residue at the $N$-terminus of the nature $\mathrm{GH}$ remains to be determined. However, as shown in Fig. 2, we predicted that the first 17 aa residues might comprise the signal peptide, as evident from its high hydrophobicity, and the remaining 187 aa residues might comprise the mature GH polypeptide. The $N$-terminus aa residue of the mature ypGH may, therefore, start with glutamine which was also observed in the GHs of red seabream (Momota et al., 1988) and bluefin tuna (Sato et al., 1988). The first aa residue of the mature eel GH started with valine (Saito et al., 1988) and that of chum salmon, coho salmon and rainbow trout GH started with isoleucine (Sekine et al., 1985; Agellon and Chen, 1986; Gonzalez-Villasenor et al., 1988). The number of a residues in the signal peptide of yp-pre-GH was the same as that reported for the red seabream (Momota et al., 1988) and bluefin tuna (Sato et al., 1988), but two residues fewer than the signal peptide of eel (Saito et al., 1988) and five residues fewer than that of chum salmon (Sekine et al., 1985), rainbow trout (Agellon and Chen, 1986)

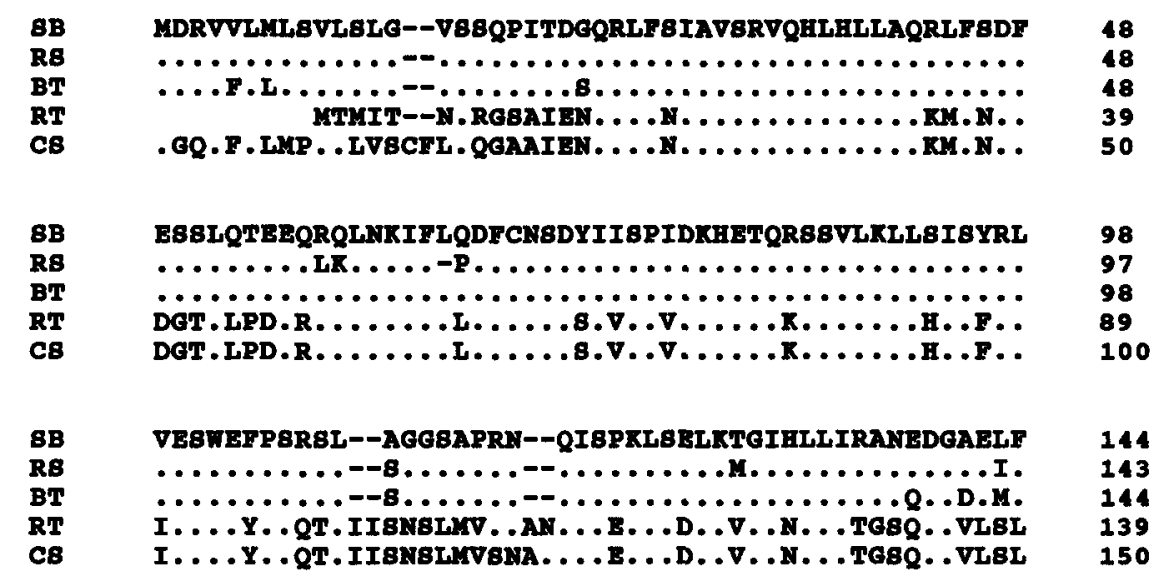

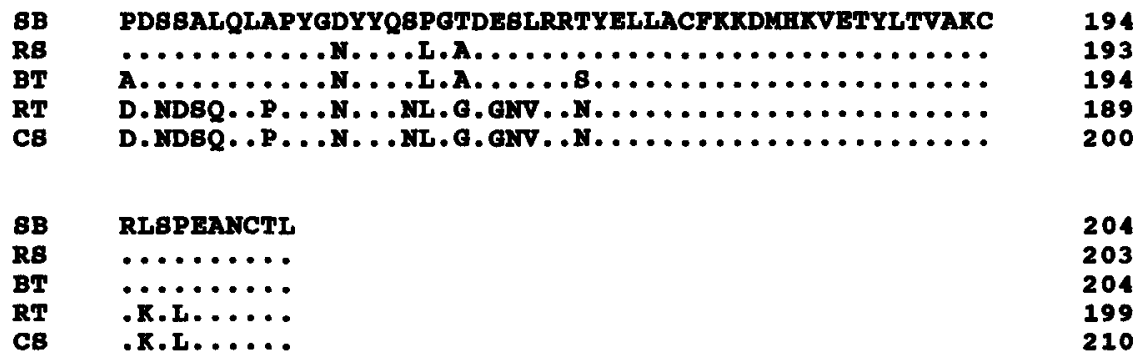

Fig. 3. Comparison of the predicted aa sequence of yp-pre-GH (SB) with that of red seabream (RS, Momota et al., 1988), bluefin tuna (BT, Sato et al., 1988), chum salmon (CS, Sekine et al., 1985) and rainbow trout (RT, Agellon and Chen, 1986). Numbers start at the first aa residue; the identical aa residues are indicated by dots. "-.", gaps created to maximize the degree of homology among all of the sequences compared. 
and coho salmon (Gonzalez-Villasenor et al., 1988). When the mature ypGH was compared to the GHs of other fish species, it was observed that ypGH was in the same size range as that of bluefin tuna, but one residue shorter than that of chum salmon (Sekine et al., 1985), coho salmon (Gonzalez-Villasenor et al., 1988), rainbow trout (Agellon and Chen, 1986), red seabream (Momota et al., 1988), rat (Seeburg et al., 1977), human (Martial et al., 1979) and cow (Miller and Eberhardt, 1983).

Figure 3 summarizes the comparison of the aa sequence of ypGH with $\mathrm{GH}$ of other fish species. The ypGH shared a $95.1 \%$ homology with that of the red seabream, $94.1 \%$ with bluefin tuna, $65.3 \%$ with rainbow trout (GH-I) and $62.4 \%$ with chum salmon (GH-I). The results of a sequence comparison are incongruous with the taxonomical classification of these fish. Yellowfin porgy, red seabream and tuna are classified as order Perciformes, whereas rainbow trout, coho salmon and chum salmon are order Salmoniformes. Moreover, yellowfin porgy and red seabream belong to suborder Percoidei and tuna belongs to suborder Scombroidei. This reflects that the $n t$ sequence encoded for the translated region of ypGH cDNA shared a 96.2 and $90 \%$ identity at the nt sequence level with that of red seabream and tuna.

Upon closer examination of the primary structures of ypGH and GHs of other fish and mammals, two additional specific features of ypGH were also observed. A highly conserved region existed near the $C$-terminus (Leu-174 to Arg-195) of the GH molecule, which was almost identical among fish species studied to date, and shared $64 \%$ homology with $\mathrm{GH}$ of humans or other mammals. Results of X-ray crystallographic studies of porcine GH suggested that this highly conserved region of the molecule might be important in the formation and stabilization of $\mathrm{GH}$ specific conformation (Abdel-Meguid et al., 1987). Furthermore, there were four cysteine residues at locations nearly identical to those in the GHs of other fish species and mammals. Since the contribution of cysteine residues in the formation of the tertiary structure as well as the maintenance of growthpromoting activity in mammalian $\mathrm{GH}$ has been well established (Paladini et al., 1981; Abdel-Meguid et al., 1987), the cysteine found in ypGH may play a similar role.

\section{Frequency of codon usage}

The nt codon usage in yp-pre-GH is summarized in Table 1. As in the pre-GH of chum salmon (Sekine et al., 1985), tuna (Sato et al., 1988) and humans (Masuda et al., 1988), the codons used in yp-pre-GH were rather non-random. The preferentially used codons were as described by Maruyama et al. (1986): CTG for leucine, GTG for valine, GGC for glycine, ATC for isoleucine, TAC for tyrosine, CAC for histidine, CAG for glutamine, AAC for asparagine, GAC for aspartic acid, GAG for glutamic acid and TTC for phenylalanine. However, there were some
Table 1. Codon usage in GH cDNA

\begin{tabular}{|c|c|c|c|c|c|}
\hline \multirow[b]{2}{*}{ aa } & \multirow[b]{2}{*}{ Codon } & \multicolumn{4}{|c|}{ Species } \\
\hline & & YP & BT & $\mathrm{CS}$ & $\mathrm{HU}$ \\
\hline leu & $\begin{array}{l}\text { UUA } \\
\text { UUG } \\
\text { CUU } \\
\text { CUC } \\
\text { CUA } \\
\text { CUG }\end{array}$ & $\begin{array}{r}\overline{2} \\
1 \\
9 \\
1 \\
17\end{array}$ & $\begin{array}{l}\overline{2} \\
1 \\
8 \\
\frac{8}{20}\end{array}$ & $\begin{array}{r}1 \\
4 \\
6 \\
2 \\
20\end{array}$ & $\begin{array}{r}\frac{1}{2} \\
2 \\
10 \\
4 \\
15\end{array}$ \\
\hline $\arg$ & $\begin{array}{l}\text { CGU } \\
\text { CGC } \\
\text { CGA } \\
\text { CGG } \\
\text { AGA } \\
\text { AGG }\end{array}$ & $\begin{array}{l}2 \\
1 \\
3 \\
5 \\
2\end{array}$ & $\begin{array}{l}3 \\
1 \\
2 \\
1 \\
4 \\
2\end{array}$ & $\begin{array}{l}1 \\
\frac{1}{2} \\
2 \\
3\end{array}$ & $\begin{array}{l}\frac{1}{4} \\
\frac{2}{5}\end{array}$ \\
\hline ser & $\begin{array}{l}\text { UCU } \\
\text { UCC } \\
\text { UCA } \\
\text { UCG } \\
\text { AGU } \\
\text { AGC }\end{array}$ & $\begin{array}{r}11 \\
4 \\
2 \\
2 \\
2 \\
5\end{array}$ & $\begin{array}{r}11 \\
4 \\
3 \\
2 \\
1 \\
8\end{array}$ & $\begin{array}{l}4 \\
3 \\
2 \\
4 \\
6\end{array}$ & $\begin{array}{l}3 \\
7 \\
2 \\
1 \\
3 \\
5\end{array}$ \\
\hline val & $\begin{array}{l}\text { GUU } \\
\text { GUC } \\
\text { GUA } \\
\text { GUG }\end{array}$ & $\frac{1}{\frac{3}{6}}$ & $\begin{array}{l}1 \\
\frac{4}{4}\end{array}$ & $\begin{array}{l}-\overline{9} \\
1 \\
4\end{array}$ & $\frac{\overline{3}}{4}$ \\
\hline pro & $\begin{array}{l}\mathrm{CCU} \\
\mathrm{CCC} \\
\mathrm{CCA} \\
\mathrm{CCG}\end{array}$ & $\begin{array}{l}2 \\
3 \\
2 \\
2\end{array}$ & $\begin{array}{l}-\overline{1} \\
4 \\
2\end{array}$ & $\begin{array}{l}2 \\
2 \\
2 \\
-\end{array}$ & $\begin{array}{l}-6 \\
1 \\
1\end{array}$ \\
\hline thr & $\begin{array}{l}\text { ACU } \\
\text { ACC } \\
\text { ACA } \\
\text { ACG }\end{array}$ & $\begin{array}{r}1 \\
4 \\
4 \\
-\end{array}$ & $\begin{array}{l}- \\
2 \\
4 \\
1\end{array}$ & $\begin{array}{l}2 \\
4 \\
1\end{array}$ & $\begin{array}{l}1 \\
4 \\
5 \\
2\end{array}$ \\
\hline ala & $\begin{array}{l}\text { GCU } \\
\text { GCC } \\
\text { GCA } \\
\text { GCG }\end{array}$ & $\begin{array}{r}5 \\
4 \\
2 \\
-\end{array}$ & $\begin{array}{r}7 \\
4 \\
1 \\
-\end{array}$ & $\begin{array}{l}1 \\
3 \\
2 \\
2\end{array}$ & $\begin{array}{l}3 \\
5 \\
1 \\
-\end{array}$ \\
\hline gly & $\begin{array}{l}\text { GGU } \\
\text { GGC } \\
\text { GGA } \\
\text { GGG }\end{array}$ & $\begin{array}{l}1 \\
5 \\
2 \\
-\end{array}$ & $\begin{array}{c}\frac{2}{5} \\
-\end{array}$ & $\begin{array}{l}1 \\
3 \\
2 \\
4\end{array}$ & $\frac{\overline{8}}{3}$ \\
\hline ile & $\begin{array}{l}\text { AUU } \\
\text { AUC } \\
\text { AUA }\end{array}$ & $\begin{array}{l}1 \\
9 \\
-\end{array}$ & $\frac{-}{10}$ & $\begin{array}{l}2 \\
7 \\
2\end{array}$ & $\begin{array}{r}2 \\
5 \\
-\end{array}$ \\
\hline tyr & $\begin{array}{l}\text { UAU } \\
\text { UAC }\end{array}$ & $\begin{array}{l}2 \\
5\end{array}$ & $\begin{array}{l}4 \\
3\end{array}$ & $\overline{6}$ & $\begin{array}{l}1 \\
5\end{array}$ \\
\hline his & $\begin{array}{l}\mathrm{CAU} \\
\mathrm{CAC}\end{array}$ & $\begin{array}{l}1 \\
4\end{array}$ & $\begin{array}{l}1 \\
4\end{array}$ & $\begin{array}{l}1 \\
4\end{array}$ & $\begin{array}{l}1 \\
2\end{array}$ \\
\hline $\operatorname{gln}$ & $\begin{array}{l}\text { CAA } \\
\text { CAG }\end{array}$ & $\begin{array}{l}3 \\
9\end{array}$ & $\begin{array}{l}4 \\
9\end{array}$ & $\begin{array}{l}3 \\
9\end{array}$ & $\begin{array}{l}3 \\
9\end{array}$ \\
\hline asn & $\begin{array}{l}\text { AAU } \\
\text { AAC }\end{array}$ & $\begin{array}{l}1 \\
4\end{array}$ & $\begin{array}{l}1 \\
5\end{array}$ & $\begin{array}{r}2 \\
13\end{array}$ & $\overline{9}$ \\
\hline lys & $\begin{array}{l}\text { AAA } \\
\text { AAG }\end{array}$ & $\begin{array}{l}5 \\
4\end{array}$ & $\begin{array}{l}3 \\
6\end{array}$ & $\begin{array}{r}2 \\
10\end{array}$ & $\begin{array}{l}1 \\
6\end{array}$ \\
\hline asp & $\begin{array}{l}\text { GAU } \\
\text { GAC }\end{array}$ & $\begin{array}{l}4 \\
7\end{array}$ & $\begin{array}{l}3 \\
7\end{array}$ & $\begin{array}{r}3 \\
10\end{array}$ & $\begin{array}{l}2 \\
9\end{array}$ \\
\hline glu & $\begin{array}{l}\text { GAA } \\
\text { GAG }\end{array}$ & $\begin{array}{r}1 \\
12\end{array}$ & $\begin{array}{l}3 \\
9\end{array}$ & $\begin{array}{l}3 \\
6\end{array}$ & $\begin{array}{l}3 \\
9\end{array}$ \\
\hline cys & $\begin{array}{l}\text { UGU } \\
\text { UGC }\end{array}$ & $\begin{array}{l}3 \\
1\end{array}$ & $\begin{array}{l}1 \\
3\end{array}$ & $\begin{array}{l}2 \\
3\end{array}$ & $\begin{array}{l}2 \\
3\end{array}$ \\
\hline phe & $\begin{array}{l}\text { UUU } \\
\text { UUC }\end{array}$ & $\begin{array}{l}1 \\
7\end{array}$ & $\begin{array}{l}2 \\
7\end{array}$ & $\begin{array}{l}2 \\
7\end{array}$ & $\begin{array}{l}4 \\
9\end{array}$ \\
\hline trp & UGG & 1 & 1 & 1 & 2 \\
\hline met & AUG & 3 & 3 & 5 & 3 \\
\hline
\end{tabular}

Numbers indicate the frequency with which the codons are used in the coding region of $\mathrm{GH}$ mRNA. aa, amino acid; YP, yellowfin porgy; BT, bluefin tuna; CS, chum salmon; HU, human. 
exceptions: (i) TGT preferentially for cysteine in yp-pre-GH and TGC for pre-GH of tuna, salmon and human; (ii) TCT preferentially for serine in pre-GH of yellowfin porgy and tuna, but $\mathrm{AGC}$ and TCC for pre-GH of salmon and human; (iii) AGA preferentially for arginine in pre-GH of yellowfin porgy and tuna, but $A G G$ or CGC for pre-GH of salmon and human. Although codon CGG is not used in the pre-GH of yellowfin porgy, it is preferentially used in the pre-GH of tuna, salmon and human.

\section{Expression}

In order to confirm that the ypGH cDNA clone indeed encodes the GH polypeptide, the cDNA insert was amplified by PCR and ligated into an expression vector, pRE, following the scheme outlined in Fig. 4. The resulting plasmid was introduced into $E$. coli cells, induced at $41^{\circ} \mathrm{C}$ and the protein products were analyzed by SDS-PAGE and by immunoprecipitation.

A protein band around $23 \mathrm{kDa}$ was detected in $E$. coli harboring pREYP after heat induction for $2 \mathrm{hr}$ (Fig. 5A). This protein band was absent in cells containing $\mathrm{pRE}$. Immunoblot analysis showed that this protein band reacted specifically with a $\mathrm{GH}$ antibody (Fig. 5B). Based on the staining intensity of different protein bands on the gels, the amount of rGH was estimated to be more than $5 \%$ of the total

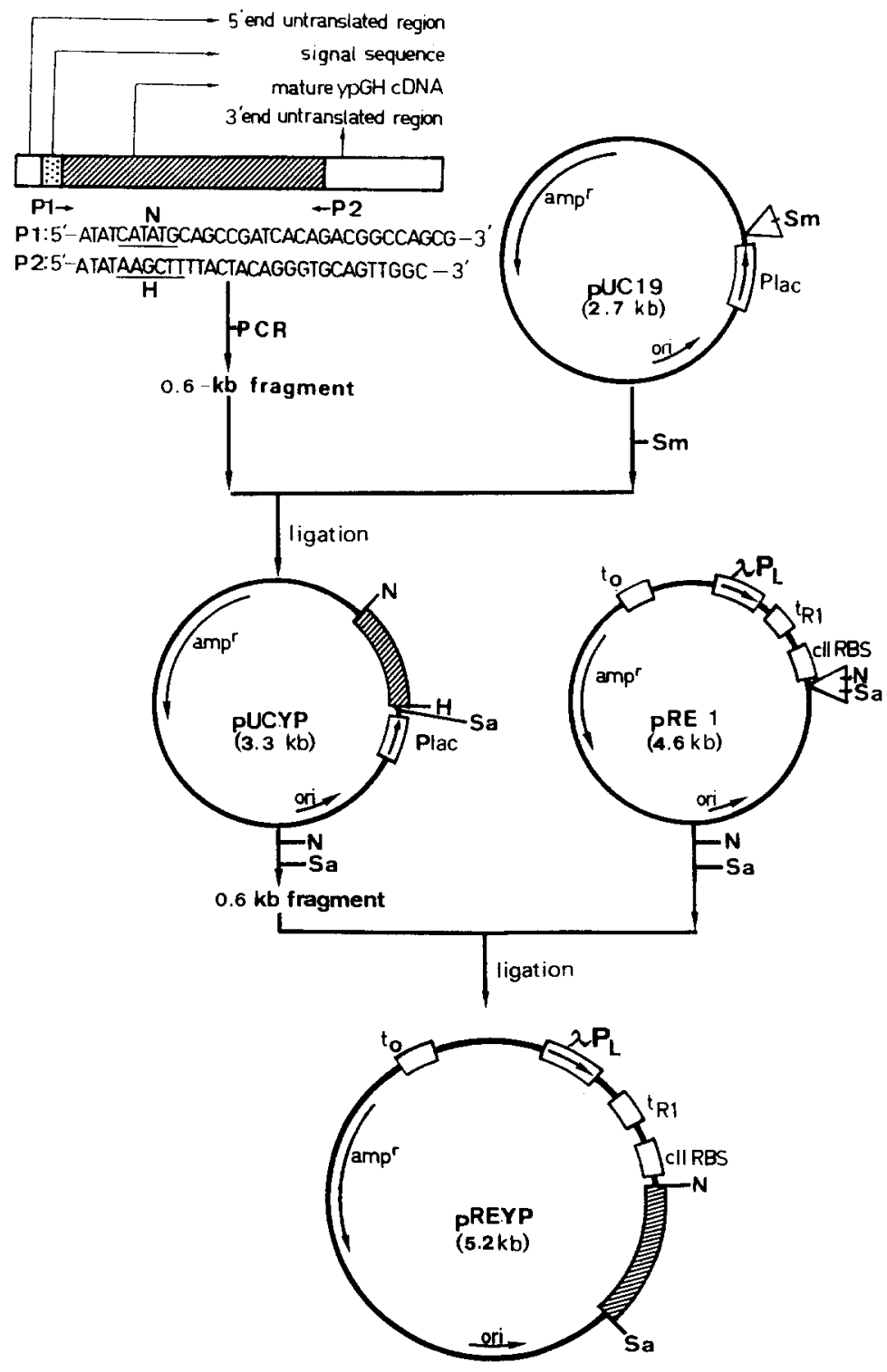

Fig. 4. Construction of the pREYP, a plasmid of $5.2 \mathrm{~kb}$ for the expression of ypGH cDNA. The $\mathrm{nt}$ sequence for the signal peptide and the mature ypGH are indicated by a stippled box and a hatched box, respectively. The empty box represents the $S^{\prime}$ and $3^{\prime}$-untranslated regions. $\mathbf{P 1}$ and $\mathrm{P} 2$ are the primers used to amplify the entire ypGH cDNA by PCR. amp, Ampicillin resistance gene; ori, origin of plasmid replication; $P_{L}$, lambda $P_{L}$ promoter; $P_{\text {lac }}$, lac promoter; $R B S$, ribosome binding site; $t_{o}$ and $t_{R 1}$, transcription terminator. Arrow shows the transcription direction. H, HindIII; N, Nde I; Sa, SalI; Sm, Sma I sites. 
A

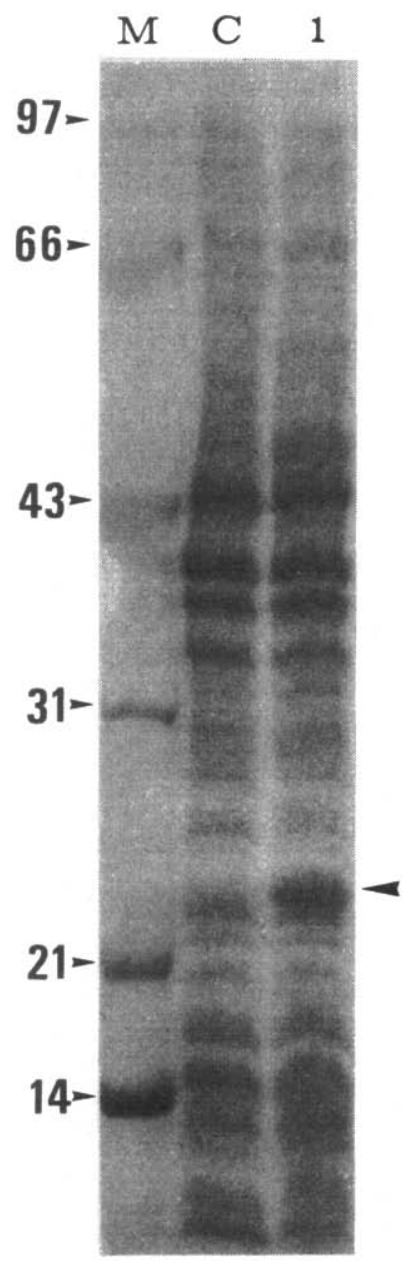

B

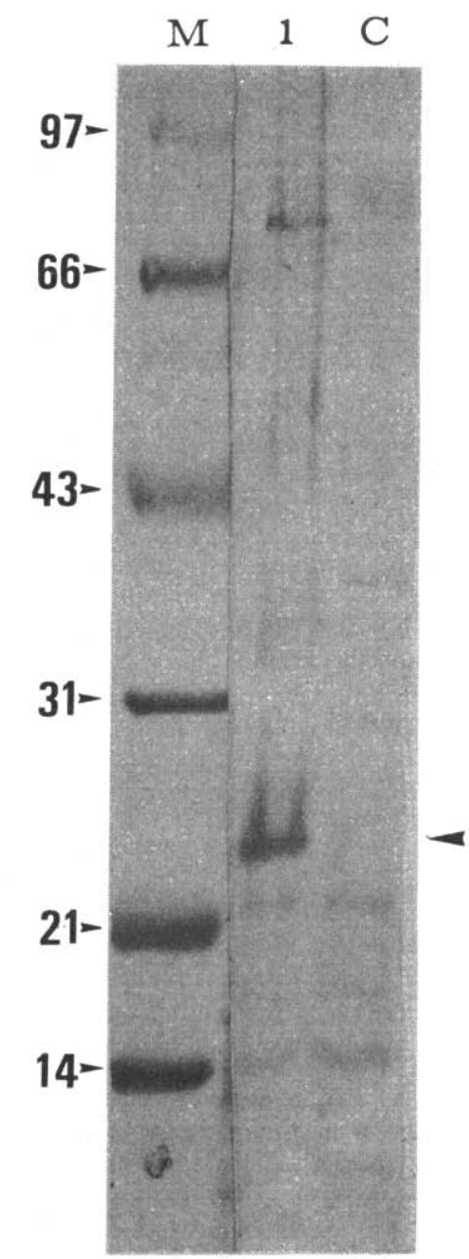

Fig. 5. Expression of ypGH in E. coli MZ-1 (lambda cI857 lysogen). Cells were cultured in superbroth medium with $50 \mu \mathrm{g} / \mathrm{ml}$ ampicillin at $30^{\circ} \mathrm{C}$ until the $\mathrm{OD}_{650}$ reached 0.5 . Then, the cultivation temperature was shifted to $41^{\circ} \mathrm{C}$ for the induction of ypGH synthesis. Cells were harvested after $2 \mathrm{hr}$ induction and their proteins were analyzed by SDS-PAGE on a $20 \%$ gel with Coomassie Blue staining (A) and by immunoblotting using polyclonal antiserum raised against the natural csGH for immunoreaction (B). Lane $\mathrm{M}$ : proteins molecular marker in kilodaltons $(\mathrm{kDa})$; lane $\mathrm{C}$ : a culture containing the cloning vector alone serving as a control; lane 1: a culture harboring pREYP (with ypGH cDNA insert). The arrows indicate the biosynthetic ypGH.

bacterial proteins. Since the biosynthetic GH produced in $E$. coli cells forms insoluble inclusion bodies, they can be readily isolated and purified from the cell extract by differential centrifugation and washing. Thus this $E$. coli strain can be used for a large-scale production of biosynthetic $\mathrm{rGH}$ for basic research and for aquaculture applications.

Acknowledgements - We thank Miss Ling-hui Li for her technical assistance. This work was supported by grants from the National Science Council (NSC78-0209-B002-01 and NSC79-0209-B002-04), Republic of China, to HJT.

\section{REFERENCES}

Abdel-Meguid S. S., Shieh H. S., Smith W. W., Dayringer H. E., Village M. O. and Bentle L. A. (1987) Three- dimensional structure of a genetically engineered variant of porcine growth hormone. Proc. natn. Acad. Sci. U.S.A. 84, $6434-6437$.

Agellon L. B. and Chen T. (1986) Rainbow trout growth hormone: molecular cloning of cDNA and expression on Escherichia coli. DNA 5, 463-471.

Agellon L. B., Davies S. L., Chen T. T. and Powers D. A. (1988) Structure of a fish (rainbow trout) growth hormone gene and its evolutionary implications. Proc. natn. Acad. Sci. U.S.A. 85, $5136-5140$.

Aviv H. and Leder P. (1972) Purification of biologically active globin messenger RNA by chromatography on oligothymidylic acid cellulose. Proc. natn. Acad. Sci. U.S.A. 69, 1408-1412.

Chan Y. L., Gutell R., Noller H. F. and Wool I. G. (1984) The nucleotide sequence of a rat $18 \mathrm{~S}$ ribosomal ribonucleic acid gene and a proposal for the secondary structure of $18 \mathrm{~S}$ ribosomal RNA. J, biol. Chem. 259, 224-230. 
Chang, C. F. and Yueh W. S. (1990) Annual cycle on gonadal histology and steriodal profile in the juvenile males and adult females of the protandrous black porgy, Acanthopagrus schleigeli. Aquaculture 91, 176-196.

Chen T. T. (1980) Vitellogenin in locusts (Locusta migratoria): Translation of vitellogenin mRNA in Xenopus oocytes and analysis of polypeptide products. Arch. Biochem. Biophys. 201, 266-276.

Chiou C. S., Chen H. T. and Chang W. C. (1990) The complete nucleotide sequence of the growth hormone gene from the common carp Cyprinus carpio. Biochim. Biophys. Acta 1087, 91-94.

Funkenstein B., Chen T. T., Powers D. A. and Cavari B. (1991) Cloning and sequencing of the gilthead seabream (Sparus aurata) growth hormone-encoding cDNA. Gene 103, 243-247.

Gonzalez-Villasenor L. I., Zhang P. J., Chen T. T. and Power D. A. (1988) Molecular cloning and sequencing of coho salmon growth hormone cDNA. Gene 65 , 239-246.

Hames B. D. (1990) One-dimensional polyacrylamide gel electrophoresis. In Gel Electrophoresis of Proteins: A Practical Approach (Edited by Hames B. D. and Richwood D.), second edition, pp. 30-50. Oxford University Press, New York.

Hew C., Trinh K. Y., Du S. J. and Song S. (1989) Molecular cloning and expression of salmon pituitary hormones. Fish Physiol. Biochem. 7, 375-380.

Innis M. A. and Gelfand D. H. (1990) Optimization of PCRs. In PCR Protocols (Edited by Innis M. A., Gelfand D. H., Sninsky J. J. and Hite T. J.), pp. 1-12. Academic Press, San Diego.

Johansen B., Johnsen O. C. and Valla S. (1989) The complete nucleotide sequence of the growth-hormone gene from Atlantic salmon (Salmo salar). Gene 77, 317-324.

Laemmli U. K. (1970) Cleavage of structural proteins during the assembly of the head of bacteriophage T4 Nature 227, 680-685.

Maniatis T., Fritsch E. F. and Sambrook J. (1982) Molecular Cloning. Cold Spring Harbor Laboratory, Cold Spring Harbor, NY.

Martial J. A., Hallwell R. A., Baxter J. D. and Goodman H. M. (1979) Human growth hormone: complementary DNA cloning and expression in bacteria. Science $\mathbf{2 0 5}$, 602-606.

Maruyama T., Gojobori A. S. and Ikemura T. (1986) Codon usage tabulated from the GeneBank genetic sequence data. Nucleic Acids Res. 14, 151-197.

Masuda N., Watahiki M., Tanaka M., Yamakawa M. Shimizu K., Nagai J. and Nakashima K. (1988) Molecular cloning encoding $20 \mathrm{kDa}$ variant human growth hor- mone and the alternative splicing mechanism. Biochim. Biophys. Acta 949, 125-131.

Miller W. L. and Eberhardt N. L. (1983) Structure and evolution of the growth hormone gene family. Endocrinol. Rev. 4, 97-129.

Momota H., Kosugi R., Hiramatsu H., Ohgai H., Hara A. and Ishioka H. (1988) Nucleotide sequence of cDNA the pregrowth hormone of red seabream (Pagrus major). Nucleic Acids Res. 16, 3107.

Nakashima K., Darzynkiewicz E. and Shatkin A. J. (1980) Proximity of mRNA 5'-region and $18 \mathrm{~S}$ rRNA in eukaryotic initiation complex. Nature 286, 226-230.

Paladini A. C., Pena C. and Poskus E. (1981) Molecular biology of growth hormones. CRC Crit. Rev. Biochem. $15,25-56$.

Reddy P., Peterkofsky A. and McKenney K. (1989) Hyperexpression and purification of Escherichia coli adenylate cyclase using a vector designed for expression of lethal gene products. Nucleic Acids Res. 17, 10473-10488.

Rentier-Delrue F., Swennen D., Philippart J. C., Lhoir C., Lion M., Benrubi O. and Martial J. A. (1989) Tilapia growth hormone-molecular cloning of cDNA and expression in Escherichia coli. DNA 8, 271-278.

Saito A., Sekine S., Komatsu Y., Sato M., Hirano T. and Itoh S. (1988) Molecular cloning of eel growth hormone cDNA and its expression in Escherichia coli. Gene 73 , 545-551.

Sanger F., Nicklen S. and Coulson A. R. (1977) DNA sequencing with chain termainating inhibitors. Proc. natn. Acad. Sci. U.S.A. 74, 5463-5467.

Sato N., Watanabe K., Murata K., Sakaguchi M., Kariya Y., Kimura S., Nonaka M. and Kimura A. (1988) Molecular cloning and nucleotide sequence of tuna growth hormone cDNA. Biochim. Biophys. Acta 949, 35 42.

Seeburg P. H., Shine J., Martial J. A., Baxter J. D. and Goodman H. M. (1977) Nucleotide sequence and amplification in bacteria of structural gene for rat growth hormone. Nature 270, 486-494.

Sekine S., Mizukami T., Nishi T., Kuwana Y., Saito A., Sata M., Itoh S. and Kawauchi H. (1985) Cloning and expression of cDNA for salmon growth hormone in Escherichia coli. Proc. natn. Acad. Sci. U.S.A. 82, $4306-4310$.

Sekine S., Mizukami T., Saito A. and Kawauchi H. (1989) Isolation and characterization of a novel growth hormone cDNA from chum salmon (Oncorhynchus keta). Biochim. Biophys. Acta 1009, 117-120.

Towbin H., Staehelin T. and Gordon J. (1979) Electrophoretic transfer of proteins from polyacrylamide gels to nitrocellulose sheets: procedure and some applications. Proc. natn. Acad. Sci. U.S.A. 76, 4350-4354. 